\title{
Korytarze rekreacji pieszej i rowerowej jako środek ksztaltowania nowych przestrzeni publicznych Rzeszowa
}

\author{
Maciej Piekarski, Aleksandra Prokopska \\ Zakład Projektowania Architektonicznego i Grafiki Inżynierskiej, \\ Wydział Budownictwa, Inżynierii Środowiska i Architektury, Politechnika Rzeszowska, \\ e-mail:mgpiekar@prz.edu.pl,aprok@prz.edu.pl
}

Streszczenie: Tematyka opracowania dotyczy zagadnień selekcji fragmentów struktury miejskiej istotnych dla historii i tradycji Rzeszowa oraz integracji miejsc mniej eksponowanych z obszarem intensywnie eksploatowanej przestrzeni publicznej, w celu wzmocnienia wśród mieszkańców ich poczucia utożsamienia się z miastem. Charakterystycznymi zmianami struktury przestrzennej Rzeszowa są jej rozrost oraz osłabienie zwartości przestrzeni publicznej na historycznym obszarze miasta. Problemem staje się znaczne natężenie ruchu samochodowego. Zanik funkcji publicznych w obrębie centrum jest spowodowany m.in. dostępnością dla samochodów większości ulic w tym obszarze. Jedyną enklawą ruchu wyłącznie pieszego i rowerowego jest strefa obejmująca Rynek, ulice Kościuszki i 3 Maja oraz fragmenty ulic Mickiewicza i Grunwaldzkiej. Drugą taką strefą są tereny rekreacyjne nad rzeką Wisłok. Oba obszary cieszą się popularnością wśród społeczności Rzeszowa, lecz w opinii autorów, nie zaspokajają potrzeb. W pracy przedstawiano pomysł połączenia obu obszarów oraz włączenia do strefy ruchu pieszego i rowerowego innych, aktualnie odseparowanych, terenów o historycznym rodowodzie, w tym parków. Istotnym elementem koncepcji są bezkolizyjne skrzyżowania wytyczonych tras z arteriami ruchu samochodowego, z zastosowaniem przejść podziemnych, które dzięki konfiguracji terenu dostępne byłyby za pomocą pochylni, a ich przestrzenie doświetlone światłem słonecznym i dostępne wizualnie z zewnątrz. Proponowane rozwiązania wzmacniają istniejącą infrastrukturę eliminując bariery psychologiczne i funkcjonalne.

Słowa kluczowe: Rzeszów, przestrzeń publiczna, tożsamość miejska, krajobraz kulturowy.

\section{Wprowadzenie}

Rzeszów jest miastem, które na skutek sprzyjających okoliczności, jakimi były budowa inwestycji związanych z COP-em, ustanowienie siedziby województwa w roku 1944 oraz kumulacja korzyści ze zmian politycznych po 1989 roku, doświadczyło wyjątkowo intensywnego rozwoju. W jego rezultacie miasto zwiększyło na przestrzeni osiemdziesięciu lat piętnastokrotnie swoją powierzchnię oraz odnotowało ośmiokrotny wzrost liczby ludności. Jednymi z konsekwencji przemian są przekształcenie przestrzeni miejskiej na pierwotnym obszarze Rzeszowa oraz masowa migracja ludności do miasta. Obecne zmiany w obrębie historycznego układu urbanistycznego, uzasadnione jego dostosowaniem do potrzeb ruchu samochodowego, jak również sama intensywność tego ruchu, doprowadziły do utraty spójności przestrzeni publicznej, zwłaszcza w kontekście jej użytkowania przez pieszych oraz rowerzystów. Problem braku spójności miasta jest przez współczesną urbanistykę postrzegany 
jako ważny, ze względu na zagrożenie dla tożsamości miasta, a pośrednio indywidualnej tożsamości jego mieszkańców [1]. Postulowane jest dążenie do ochrony i eksponowania wartości krajobrazu kulturowego, a wszędzie tam, tam gdzie ucierpiał na skutek popełnionych w przeszłości błędów, do jego odbudowy [2].

Waga problemu rewaloryzacji i rewitalizacji historycznego układu przestrzennego Rzeszowa wynika nie tylko z akceptacji kluczowej roli centrum w strukturze miasta spójnego [1], jako obszaru, z którego emanuje jego „genius loci”, ale również z indywidualnych cech przestrzeni publicznej Rzeszowa. Na skutek ekspansji terytorialnej miasta, znaczna część zabudowy mieszkaniowej, zwłaszcza jednorodzinnej, znajduje się w rozproszeniu, co skutkuje niedostatkiem obszarów, których charakter jest określany w hierarchicznej strukturze przestrzeni komunalnych jako pólpubliczny [3]. Ogólnomiejska przestrzeń publiczna jest zmuszona przejąć oprócz typowych dla niej funkcji również takie, które mogłyby być zaspokajane lokalnie. Z jednej strony, jest to stosunkowo łatwe, ponieważ wielkość miasta umożliwia sporej części mieszkańców dotarcie do historycznego centrum pieszo lub za pomocą roweru, $z$ drugiej - rozproszenie struktury mieszkaniowej zmusza dużą grupę pozostałych do korzystania z indywidualnych środków transportu, wobec słabo rozwiniętej sieci transportu publicznego. W takiej sytuacji, radykalne ograniczenie ruchu samochodowego na obszarze centrum nie jest rozwiązaniem, które zyskałoby szeroką społeczną akceptację, natomiast dla pogodzenia interesów obu wymienionych grup należy poszukiwać rozwiązań stwarzających przestrzenną separację dedykowanych im korytarzy komunikacyjnych.

Celem badań, których rezultaty zostały przedstawione w niniejszym artykule, było opracowanie koncepcji struktury korytarzy dedykowanych dla ruchu pieszego i rowerowego, wytyczonych w taki sposób, aby łączyły utylitarność z funkcją eksponowania wartości krajobrazu kulturowego. Autorzy oparli się na znajomości topografii i materialnego dziedzictwa miasta oraz osobistym doświadczeniu, wynikającym z zamieszkiwania w Rzeszowie i prowadzenia obserwacji naukowej zjawisk i procesów istotnych z punktu widzenia architektury i urbanistyki.

\section{Przestrzeń publiczna w Rzeszowie - diagnoza stanu istniejącego}

Rozważania na temat przestrzeni publicznej, prowadzone w niniejszym opracowaniu, są oparte na definicji, określającej ją jako część przestrzeni miejskiej, która poprzez sposób urządzenia oraz lokalizację w strukturze urbanistycznej, jest miejscem realizacji bezpośrednich kontaktów pomiędzy uczestnikami życia społecznego [4]. Przestrzeń publiczna o odpowiedniej jakości motywuje ludzi do realizowania aktywności pozadomowej, kwalifikowanej jako działania opcjonalne, a więc podejmowanej w czasie wolnym i nie w wyniku bezpośredniej konieczności [3]. Podstawową aktywnością w przestrzeni publicznej jest sama w niej obecność, pozwalająca na inspirujące obserwowanie innych ludzi i krajobrazu, kształtująca świadomość identyfikacji społecznej i oddalająca poczucie wyalienowania. $Z$ takiego punktu widzenia, probierzem kwalifikowalności określonych obszarów przestrzeni miejskiej, jako przestrzeni publicznej, jest intensywność ich eksploatowania przez członków lokalnej społeczności, zwłaszcza $\mathrm{w}$ dni wolne od pracy oraz podczas sprzyjającej pogody. Jeżeli w takich warunkach, zainteresowani nie są $\mathrm{w}$ stanie realizować podstawowych aktywności, takich jak swobodny spacer, dłuższe zatrzymanie się, korzystanie z usług gastronomicznych, to wielkość lub organizację przestrzeni publicznej należy, zdaniem autorów, uznać za niezadowalające i podjąć wysiłki na rzecz powiększenia jej obszaru lub podwyższenia jakości. Symptomem tego, że przestrzeń publiczna odpowiada społecznemu zapotrzebowaniu jest mnogość obecnych w niej osób, przy relatywnie małej liczbie spacerujących [3]. 


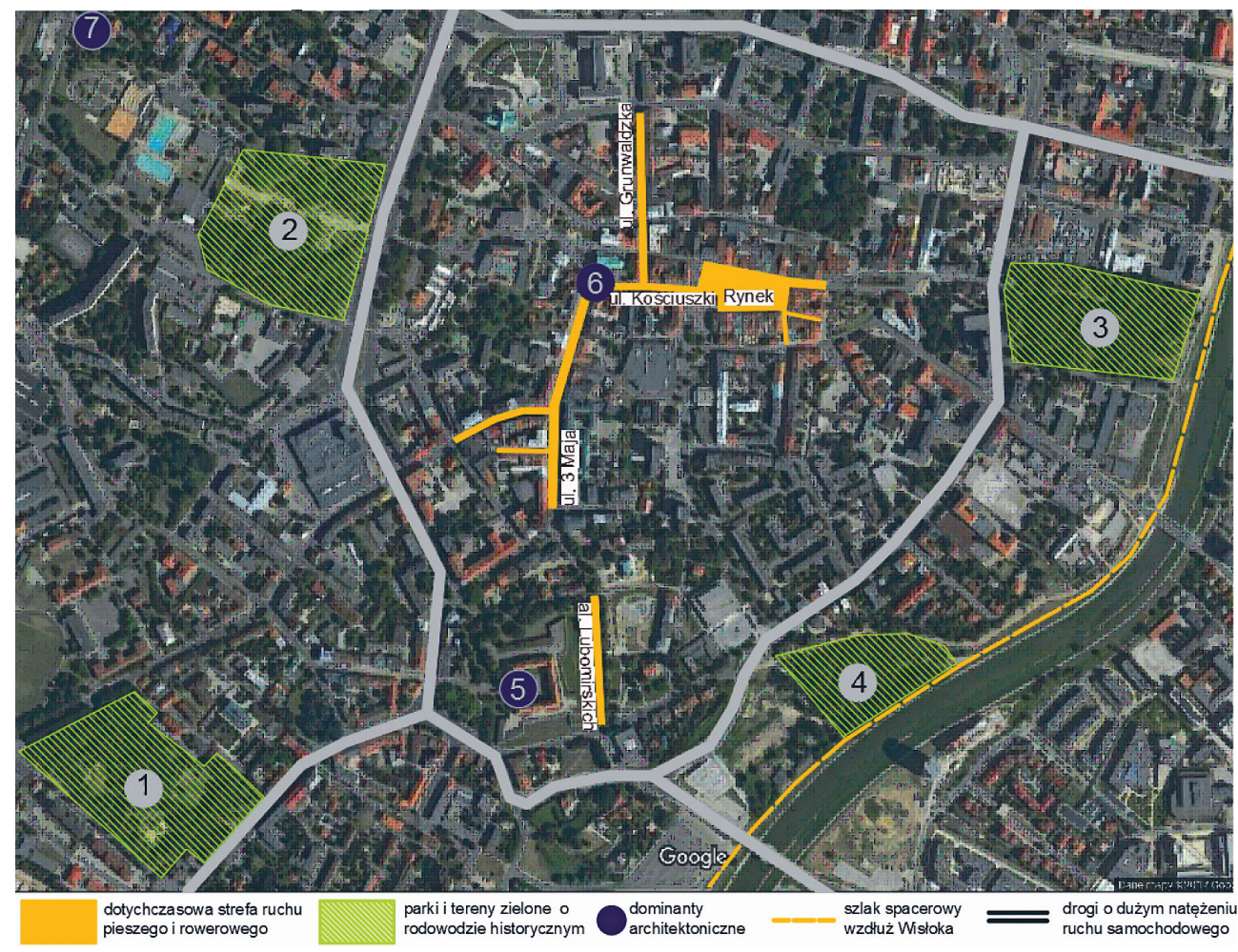

Rys. 1. Aktualna organizacja przestrzeni publicznej w centrum Rzeszowa oraz tereny zielone i dominanty architektoniczne: 1) Ogród Miejski, 2) Park Jedności Polonii z Macierzą, 3) Stary cmentarz, 4) park Olszynki, 5) wieża Zamku Lubomirskich, 6) dzwonnica kościoła farnego, 7) kopuła koscioła Chrystusa Króla

Obszarami Rzeszowa, odpowiadającymi scharakteryzowanym kryteriom przestrzeni publicznej są tereny rekreacyjne wzdłuż Wisłoka oraz fragmenty centrum, na których poprzez wyłączenie ruchu samochodowego, stworzono strefę pieszo-rowerową (rys. 1). Dla każdego z nich znamienne są inne aktywności mieszkańców. Tereny wzdłuż Wisłoka są preferowane przez amatorów czynnego wypoczynku, tj. rowerzystów, rolkarzy, biegaczy, spacerowiczów, dla których ruch na świeżym powietrzu jest ważnym motywem przebywania w przestrzeni publicznej. Takiemu wykorzystywaniu tych terenów sprzyja obecność rzeki oraz obfitość zieleni, wpływające pozytywnie na odczuwane doznania, a także wyeliminowanie przecinania się ruchu pieszego i rowerowego z ruchem samochodów. Argumentem przemawiającym za tym rozumowaniem jest zauważalny wzrost liczby użytkowników szlaku na lewym brzegu Wisłoka, w następstwie przebicia w roku 2012 tunelu pod al. Powstańców Warszawy, stanowiącą do tej daty poważną przeszkodę komunikacyjną. Istotne jest, że tunel znajduje się w niewielkim zagłębieniu, przez co nie wymaga stosowania schodów, a jego wnętrze jest dostępne wizualnie z zewnątrz, co minimalizuje poczucie zagrożenia. Aktualnie, mimo rozbudowy systemu ścieżek pieszo-rowerowych, natężenie ruchu pieszych, rolkarzy i rowerzystów jest nadal nadmiernie duże, co obniża komfort i bezpieczeństwo użytkowników. Jedyną radą wydaje się być dalsza rozbudowa systemu na terenach równie atrakcyjnych i rozproszenie zainteresowanych rekreacją w przestrzeni publicznej, na większym obszarze. 
Druga z funkcjonujących stref przestrzeni publicznej obejmuje Rynek oraz pobliskie ulice, w tym przede wszystkim Kościuszki i 3 Maja, a od czasu uruchomienia w 2015 roku fontanny multimedialnej, również otoczenie alei Lubomirskich. Na wymienionym obszarze znajdują się najbardziej cenne zabytki Rzeszowa, natomiast urzędy oraz placówki handlowe i usługowe reprezentowane są w nikłym stopniu. Użytkownikami tej strefy są przeważnie osoby piesze, zaś co jest typowe dla przestrzeni cechujących się bogactwem krajobrazu kulturowego, spora liczba osób preferuje pozostawanie przez dłuższy czas w jednym miejscu, czemu sprzyja obecność ulicznych ogródków kawiarnianych. Ponieważ możliwości dalszej ekspansji ogródków w obecnych granicach strefy uległy wyczerpaniu, zaś stały przyrost liczby mieszkańców uprawdopodabnia przyszły wzrost potrzeb również w tym zakresie, alternatywą jest przystosowanie do pełnienia funkcji przestrzeni publicznej, innych obszarów o odpowiednim potencjale. Należy pamiętać o specyfice miasta, na którą oprócz czynników wymienionych na wstępie, wpływa niski średni wiek mieszkańców, wynoszący 39 lat, wysoki odsetek osób z wyższym wykształceniem (33,5 \% osób w wieku produkcyjnym) oraz największy w Unii Europejskiej stosunek liczby studentów do liczby mieszkańców miasta (353 studentów na 1000 mieszkańców) [5]. Konsekwencją takiego profilu ludności Rzeszowa jest zwiększone zapotrzebowanie na przestrzeń publiczną i wysokie wymagania co do jej jakości.

W/w strefy przestrzeni publicznej zostały wyróżnione przez autorów ze względu na powodzenie jakim cieszą się wśród społeczności Rzeszowa oraz spójność zagospodarowania przestrzennego na stosunkowo dużym obszarze. W ich sąsiedztwie istnieje szereg innych terenów, albo wypełniających podobne zadania, lecz w mniejszym zakresie, albo ze względu na walory, predestynowanych do ich wypełniania, zwłaszcza w kontekście znaczenia dla tożsamości miasta i jego mieszkańców. Są to parki o historycznym rodowodzie, jak Ogród Miejski przy ul. Dąbrowskiego, Park Jedności Polonii z Macierzą przy al. Cieplińskiego, Plac Ofiar Getta oraz Stary Cmentarz, a także wnętrza urbanistyczne ulic i placów otoczonych zabudową o znaczących walorach architektonicznych lub wartości historycznej, takich jak place Farny i Śreniawitów oraz ulice Jagiellońska, Kraszewskiego, Reformacka, Mickiewicza, Jałowego i ich otoczenie. W opinii autorów, tereny te nie odnajdują się w roli przestrzeni publicznej na skutek braku funkcjonalnych powiązań z obszarami największej aktywności społecznej, nadmiernej obecności samochodów, a także zaniedbanej infrastruktury.

\section{Koncepcja sieci ciągów pieszo-rowerowych ukierunkowanych na synergię rekreacji i doświadczania wartości architektoniczno-kulturowych krajobrazu}

Podstawowymi założeniami koncepcji propagowanej w niniejszym opracowaniu jest połączenie terenów nadrzecznych i otoczenia Rynku oraz rozszerzenie śródmiejskiej strefy przestrzeni publicznej, przez integrujące włączenie do niej w/w parków, skwerów, placów i ulic, za pomocą funkcjonalnych ciągów pieszo-rowerowych. Zaproponowane działania mają na celu rekompozycję przestrzeni miejskiej, która poprzez aranżację osi kompozycyjnych lub uwydatnienie dominant architektonicznych, wyeksponuje walory krajobrazu kulturowego oraz zachęci do jego eksplorowania. W celu udrożnienia ruchu pieszych i rowerzystów na rewitalizowanym obszarze, proponuje się wprowadzenie na części ulic i placów całkowitego zakazu ruchu samochodów, a na innych terenach wytyczenie ciągów pieszych i rowerowych, możliwe poprzez ograniczenie ruchu samochodów i możliwości ich parkowania. 
Szczególną uwagę poświęca się zapewnieniu komfortu i bezpieczeństwa pieszym i rowerzystom w miejscach przecinania się przeznaczonych dla nich szlaków z trasami ruchu samochodów. W tym celu proponowana jest budowa przyjaznych przejść podziemnych oraz wdrożenie rozwiązań powodujących spadek natężenia ruchu samochodowego lub jego uspokojenie.

\subsection{Rozszerzenie strefy pieszo-rowerowej w centrum miasta}

Proponuje się, aby strefa zakazu ruchu samochodów została rozszerzona na ulicę Jagiellońską we fragmencie od ul. 3 Maja do ul. Zygmuntowskiej, plac Farny, ulicę Matejki, ulicę Słowackiego we fragmencie od wjazdu na parking w sąsiedztwie Ratusza do jej skrzyżowania z ul. Matejki oraz południową jezdnię ulicy Mickiewicza na całej jej długości, tj. od ul Joselewicza do ul. Kreczmara (rys. 2). Celowość zamienienia części ulicy Jagiellońskiej w ciąg pieszo-rowerowy uzasadnia się tym, że stanowi ona sięgacz, praktycznie pozbawiony możliwości zawracania, a także wartością architektoniczną budynków w pierzejach ulicy i obecnością lokali usługowych i handlowych, wpisujących się w funkcję przestrzeni publicznej, w tym lokali gastronomicznych i księgarń. Modernizacja ulicy powinna obejmować podniesienie poziomu jezdni do poziomu chodników oraz wyposażenie w obiekty małej architektury, w tym ławki i donice z zielenią.

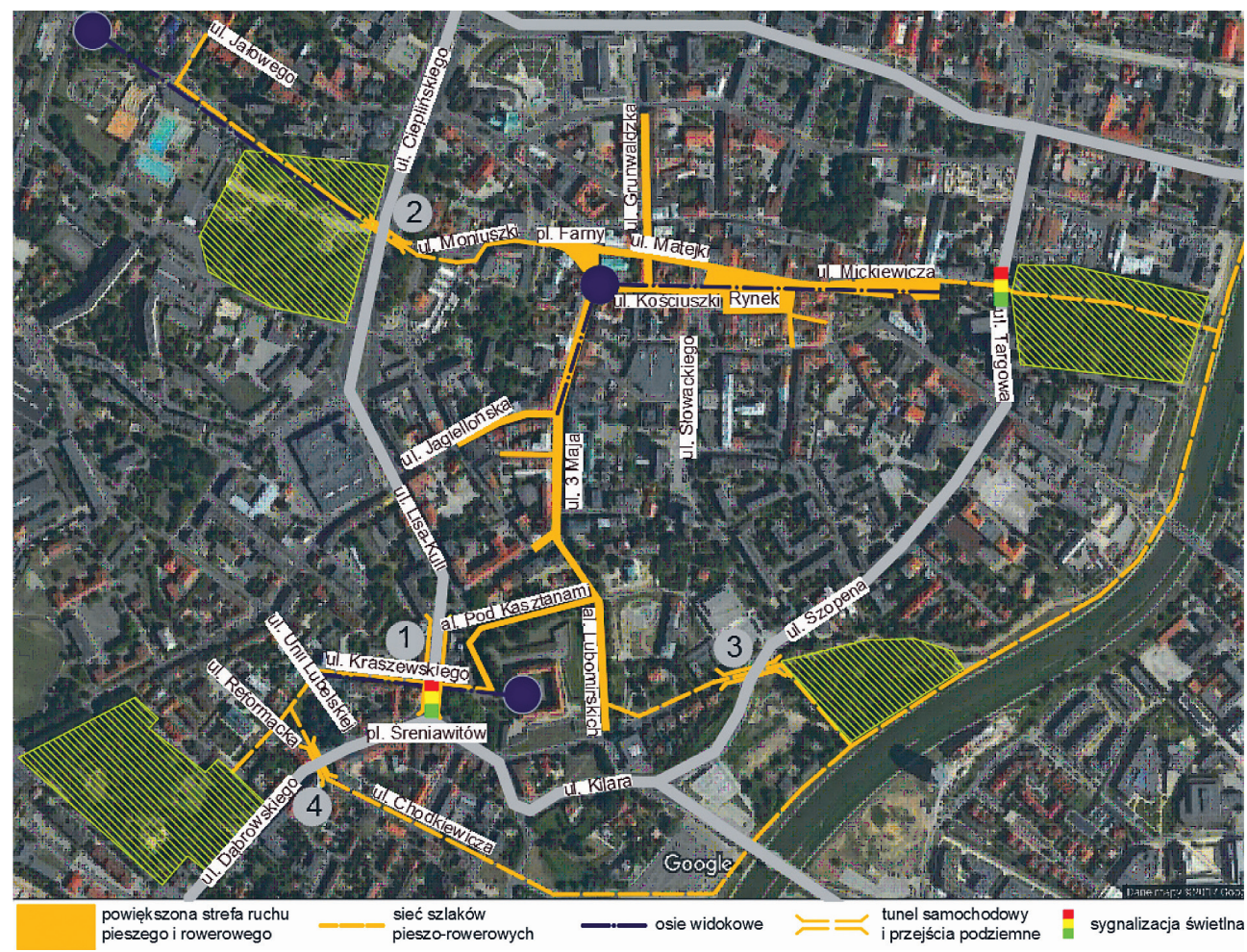

Rys. 2. Koncepcja rozbudowy przestrzeni publicznej oraz rozmieszczenie proponowanych obiektów inżynierskich: 1) tunel drogowy pod jezdnią ul. Lisa-Kuli, 2) tunel pieszo-rowerowy pod ul. Cieplińskiego, 3) tunel pieszo-rowerowy pod ul. Szopena, 4) tunel pieszo-rowerowy pod skrzyżowaniem ul. Dąbrowskiego i ul. Reformackiej 
Zamierzenie włączenia placu Farnego do strefy pieszo-rowerowej wynika z charakteru jego zabudowy. Dominantę placu stanowi kościół św. Wojciecha i św. Stanisława, którego gotyckie prezbiterium jest najstarszym zabytkiem Rzeszowa, zaś sylweta barokowej dzwonnicy kościoła, jest jednym z symboli miasta. Zabudowę placu Farnego uzupełniają XIX wieczny budynek plebanii farnej oraz pomnik płk. Leopolda Lisa-Kuli, przy którym organizowane są uroczystości patriotyczne. W obrębie placu Farnego nie znajdują się obiekty, które wymagałyby dojazdu samochodów, styka się on bezpośrednio z istniejącą strefą pieszo-rowerową, zaś ekspozycja frontonu kościoła św. Wojciecha i św. Stanisława, jest dostępna wyłącznie z przestrzeni tego placu. Wszystkie przytoczone argumenty przemawiają za wyłączeniem w jego obrębie ruchu samochodowego. Ze względu na brak zabudowy obrzeżnej, z placu otwierają się perspektywy na jego otoczenie. Oprócz obiektów ciekawych, jak modernistyczny budynek poczty przy ul. Moniuszki, ściana budynku przy ul. Sokoła 2 z umieszczoną na niej repliką planu Wiedemanna, przedstawiającego widok Rzeszowa z 1762 roku oraz przylegającej do niej zabytkowej trafiki, obejmują obiekty dysharmonijne w krajobrazie, jak budynek handlowo-gastronomiczny przy ul. Moniuszki 2, budynek NOT przy ul. Kopernika 1 oraz pawilony handlowe przy ul. Kopernika 3a. Przekształcenie placu Farnego w atrakcyjne wnętrze urbanistyczne wymaga oprócz zagospodarowania samego placu, istotnych modernizacji otaczających go budynków.

Wyłączenie ruchu samochodowego w obrębie ulicy Matejki oraz fragmentu ul. Słowackiego byłoby następstwem jego wyłączenia w obrębie placu Farnego, gdyż drożność tych ulic może być zapewniona tylko przez plac Farny. Ulica Matejki stanowi jedną z ostatnich w Rzeszowie wąskich historycznych ulic, z istniejącą zabudową pierzejową po obu stronach, w związku z czym z uwagi na swoisty koloryt oraz ofertę dostępnych usług, nadaje się doskonale do wypełniania roli przestrzeni publicznej. Rozpatrywany fragment ul. Słowackiego, po wyburzeniu w 1941 roku pierzei wschodniej, stanowi w istocie fragment przestrzeni Rynku.

Propozycję rozszerzenia strefy pieszo-rowerowej o południową jezdnię ul. Mickiewicza uzasadnia się względami kompozycyjnymi oraz bliskością w stosunku do Rynku, pozwalającą rozpatrywać tam lokalizację ogródków kawiarnianych, uzupełniających ofertę dostępną w Rynku. Atrakcyjność kompozycyjna wynika z faktu usytuowania wzdłuż osi widokowej, zamkniętej od zachodu dominantą dzwonnicy kościoła farnego, zaś od wschodu pomnikiem Adama Mickiewicza. Teren sąsiaduje od strony południowej z dobrze zagospodarowanym skwerem Cichociemnych, a od strony północnej z rozdzielającym jezdnie pasem zieleni. Mimo wyłączenia ruchu pojazdów na jezdni południowej, sugeruje się jego pozostawienie na jezdni północnej, w kierunku od ul. Gałęzowskiego do ul. Joselewicza, przez którą możliwy byłby przejazd do ul. Króla Kazimierza. Takie rozwiązanie nawiązywałoby do dawnego przebiegu ulicy Mickiewicza. Do okresu okupacji niemieckiej w przestrzeni zajmowanej przez południową jezdnię oraz pas zieleni istniała zabudowa, zaś wyodrębnione dwoma pierzejami wnętrze ulicy obejmowało przestrzeń zajmowaną dzisiaj przez północną jezdnię.

\subsection{Integracja terenów zielonych o historycznym rodowodzie z śródmiejską strefą pieszo-rowerową}

Kolejnym elementem projektu są zamierzenia, które umożliwią funkcjonalną integrację z śródmiejską strefą ruchu pieszego i rowerowego, usytuowanych w jej niedalekim sąsiedztwie Ogrodu Miejskiego, Parku Jedności Polonii z Macierzą oraz Starego Cmentarza. 
Integracja Ogrodu Miejskiego ma kluczowe znaczenie, ze względu na jego walory przyrodnicze i krajobrazowe, a także tradycję tego miejsca. Ogród, którego rodowód jest XVIII-wieczny, od końca XIX wieku, do drugiej połowy XX wieku pełnił rolę letniego salonu Rzeszowa. Na jego atrakcyjność miały wpływ kompozycja przestrzenna, cenny drzewostan oraz rozbudowana infrastruktura ogrodowa. Obecnie, ze względu na zły jej stan, ogród cieszy się minimalnym zainteresowaniem odwiedzających, ale wciąż zachowany jest jego układ kompozycyjny i wiele okazów starych drzew, co stwarza podstawę do rewitalizacji. Optymalna trasa spacerowa, łącząca ogród z przestrzenią śródmiejską to trasa wytyczona przez otoczenie zespołu Zamku Lubomirskich, stwarzająca szansę przyciągnięcia do tego urokliwego zakątka Rzeszowa większej liczby odwiedzających. Proponuje się, aby dalszy odcinek trasy został wytyczony wzdłuż ul. Kraszewskiego, a następnie przez skwer pomiędzy ulicami Unii Lubelskiej i Reformacką, prostopadle do tych ulic, i dalej poprzez teren wokół kościoła garnizonowego, wprost do ogrodu miejskiego [6]. Istotną przeszkodą, odpowiedzialną za aktualne odizolowanie ogrodu miejskiego od śródmiejskiego obszaru przestrzeni publicznej, jest przebiegająca poprzecznie ul. Lisa-Kuli, charakteryzująca się bardzo wysokim natężeniem ruchu samochodowego. W celu osłabienia tej przeszkody zaproponowane zostało przeniesienie części ruchu do tunelu zbudowanego pod obecną jezdnią [6]. Walorami tak poprowadzonego ciągu pieszo-rowerowego są położenie przy trasie budynków, których wartość architektoniczna jest w skali Rzeszowa wyjątkowa, jak np. datowany na I połowę XVIII wieku tzw. dwór Piątkowskiego, czy „dom-statek” - znakomite dzieło międzywojennej architektury modernistycznej, a także postrzegana z ul. Kraszewskiego najlepsza ekspozycja wieży zamkowej - dominanty Rzeszowa,

Trasa kolejnego projektowanego „odgałęzienia” śródmiejskiej strefy pieszo-rowerowej, w kierunku Parku Jedności Polonii z Macierzą, została zaprojektowana jako rozpoczynająca się na placu Farnym, a następnie wytyczona wzdłuż ul. Moniuszki, po czym poprzez przejście podziemne pod al. Cieplińskiego, i dalej przez teren parku wzdłuż osi widokowej, zamkniętej dominantą w postaci kopuły kościoła Chrystusa Króla. Jednym z celów proponowanego rozwiązania jest retrospekcja historycznej genezy parku, który jeszcze w okresie galicyjskim stanowił teren rekreacyjny nazywany wówczas „Małpim Gajem”. Realizacja przejścia podziemnego osłabiłaby istotną przeszkodę oddzielającą park od starego miasta, jaką stanowi dwujezdniowa al. Cieplińskiego, z trzema pasami ruchu na każdej z jezdni. Wzmocnieniu spojrzenia w głąb historii pobliskiego terenu służyłaby korekta drzewostanu, odsłaniająca nobliwy wygląd pokrytej patyną kopuły kościoła Chrystusa Króla, który jako jedyny z rzeszowskich kościołów zwieńczony jest takim właśnie dachem oraz wyprowadzenie szlaku na ul. Jałowego, wprost przed budynek II Liceum Ogólnokształcącego, drugiej pod względem wieku szkoły średniej w mieście. Ulica Jałowego, przy której usytuowany jest budynek liceum jest najciekawszą krajobrazowo ulicą starego Rzeszowa z wieloma innymi wartościowymi zabytkami.

Ostatnim terenem zielonym, który poprzez poprawę dostępu od strefy okołorynkowej, mógłby zyskać na zainteresowaniu publiczności jest Stary Cmentarz przy ul. Targowej. Cmentarz jest miejscem pochówków chrześcijańskich mieszkańców Rzeszowa, datowanych na lata od końca XVIII, do początków XX wieku. Wiele mogił jest zaniedbanych i nieczytelnych, lecz szereg nagrobków zostało starannie odnowionych. Na mogiłach kombatantów, znajdują się biało-czerwone chorągiewki z datami walk, w których uczestniczyli. Znaczenie cmentarza dla tożsamości Rzeszowa jest pierwszorzędne. Trasę szlaku prowadzącego z Rynku do Cmentarza proponuje się wytyczyć wzdłuż ul. Mickiewicza, na odcinku dwujezdniowym, po terenie rozdzielającym jezdnie, wzdłuż jezdni północnej, a dalej na 
wprost do ulicy Targowej. Zamknięciem kompozycyjnym perspektywy obserwowanej przez osoby idące w kierunku Cmentarza byłaby bryła klasycystycznego kościoła św. Trójcy, pełniącego dawniej funkcję cmentarnej kaplicy.

\subsection{Integracja nadrzecznych terenów rekreacyjnych oraz śródmiejskiej strefy pieszo-rowerowej}

Ponieważ ideą niniejszego projektu jest mobilizacja aktywnych użytkowników przestrzeni publicznej w Rzeszowie do penetrowania rejonów miasta o nie odkrytym potencjale kulturowym, kluczową kwestią jest integracja obszaru śródmiejskiego, z terenami rekreacyjnymi na lewym brzegu Wisłoka, na których aktywność rekreacyjna mieszkańców Rzeszowa jest największa. W tym celu proponuje się realizację trzech korytarzy dla komunikacji pieszo-rowerowej, których trasy nie pokrywają się z dotychczasowymi szlakami nasilonego przemieszczania się pieszych lub rowerzystów.

Przebieg jednego z nich zaprojektowano przez teren Starego Cmentarza. Główna z cmentarnych alejek prowadzi od bramy wejściowej przy ul. Targowej do tylnego ogrodzenia, usytuowanego wzdłuż nadrzecznego szlaku pieszo-rowerowego, od którego nie ma jednak wejścia na teren cmentarza. $Z$ racji odizolowania cmentarza od uczęszczanej przestrzeni publicznej, jest on tylko z rzadka odwiedzany przez zainteresowane osoby. Autorzy proponują wykonanie od strony Wisłoka drugiej bramy wejściowej na teren cmentarza oraz zorganizowanie przestrzeni przed nią w taki sposób, aby znalazło się miejsce na ławki, stojaki dla rowerów oraz tablice informujące o historii cmentarza i zachowanym w jego obrębie dziedzictwie. Ciekawa przestrzeń wejściowa stanowiłaby zaproszenie do odwiedzenia cmentarza i refleksji m.in. na temat wielokulturowej tradycji miasta, udokumentowanej w wielojęzycznych tekstach nagrobnych inskrypcji.

Kolejne połączenie obu stref przestrzeni publicznej zaprojektowano pomiędzy parkiem „Olszynki” a otoczeniem fontanny multimedialnej. Odległość dzieląca oba miejsca jest mała, lecz brak między nimi wyróżnionego korytarza komunikacyjnego. Uzasadnieniem planu są popularność fontanny multimedialnej oraz historyczny rodowód Olszynek, które przed i po wojnie, wobec braku szerokiego zagospodarowania lewego brzegu Wisłoka, stanowiły popularne miejsce wypoczynku rzeszowian. Zachowany starodrzew pochodzi z tamtych czasów. Aktualnie teren Olszynek ponownie ożywa, po zlokalizowaniu tam parku linowego i infrastruktury gastronomicznej. W opinii autorów, czynnikiem generującym ruch byłoby ułatwienie przekraczania ruchliwego ciągu ulic Szopena i Kilara za pomocą przejścia podziemnego, które w związku z lokalną konfiguracją terenu, nie wymagałoby od użytkowników dodatkowego pokonywania różnicy wysokości, zaś dostęp od strony wyżej położonej mógłby być zapewniony za pomocą pochylni.

Ostatnie proponowane połączenie przestrzeni nadrzecznej i śródmiejskiej ma na celu powiązanie otoczenia hali sportowej „Podpromie” z opisanym w poprzednim punkcie traktem spacerowym do Ogrodu Miejskiego. Realizacja tego zamierzenia wymaga wytyczenia ciągu pieszo-rowerowego przez niezagospodarowany teren w otoczeniu hali, a następnie wzdłuż ul. Chodkiewicza, aż do ul. Dąbrowskiego, znajdującej się w tym miejscu znacznie ponad poziomem ul. Chodkiewicza. Jezdnię ulicy Dąbrowskiego oraz różnicę poziomów pomiędzy obydwoma ulicami, pokonywaną obecnie za pomocą schodów terenowych, proponuje się przekraczać za pomocą przejścia podziemnego oraz pochylni zlokalizowanej w obrębie skweru znajdującego się w trójboku ulic Reformackiej, Dąbrowskiego i Unii Lubelskiej. 


\section{Przejścia podziemne jako środek służący scaleniu tkanki miejskiej}

Według poglądów propagowanych przez urbanistów, należy rezygnować z przejść podziemnych jako środków ochrony pieszych w sytuacjach przecinania się ruchu pieszego z ruchem pojazdów. Jako argument przedstawiana jest niechęć przechodniów do korzystania z takich przejść, powodowana koniecznością dwukrotnego pokonywania różnicy wysokości oraz jakością oświetlania gorszą niż na otwartej przestrzeni [7]. Stawiane są postulaty zapewnienia pieszym bezpieczeństwa innymi sposobami, takimi jak sygnalizacja świetlna lub środki uspokojenia ruchu [8]. Budowanie przejść podziemnych dopuszcza się w sytuacjach, w których konfiguracja terenu niweluje niektóre $\mathrm{z}$ w/w mankamentów.W niniejszym opracowaniu zaproponowano lokalizacje przejść podziemnych wyłącznie w takich miejscach, w których nie tylko, że pieszy lub rowerzysta zmuszony jest obecnie pokonywać różnicę wysokości wynikającą z ukształtowania terenu, ale też istnieje wystarczająco dużo miejsca, aby po wybudowaniu przejścia podziemnego jej pokonanie mogło się odbywać za pomocą pochylni (rys. 3). Ma to ogromne znaczenie nie tylko dla osób niepełnosprawnych, ale ogółu użytkowników, dla których schody stanowią zawsze pewnego rodzaju barierę psychologiczną [7]. Obecność pochylni likwiduje w większości sytuacji potrzebę stosowania wind, redukując tym samym koszty budowy i eksploatacji przejścia, a ponadto nachylenie pochylni, mniejsze niż schodów, zapewnia lepsze oświetlenie wnętrza tunelu światłem dziennym. Nawierzchnia pochylni powinna być szorstka, dla pochylni o większym nachyleniu można rozważyć zastosowanie systemu grzewczego usuwającego oblodzenie, a pochylnie o nachyleniu przekraczającym $8 \%$ powinny być zadaszone [9]. W celu ułatwienia poruszania się osobom mniej sprawnym ruchowo i niedowidzącym, wzdłuż krawędzi pochylni należy zamontować poręcze. W miejscach, w których pochylnie charakteryzują się zarówno znacznym nachyleniem, jak i długością, windy powinny zostać zainstalowane. Szczegółowe rozwiązania techniczne, zarówno samych przejść podziemnych, jak i całej trasy, powinny mieć na uwadze zapełnienie pełnej funkcjonalności dla osób niepełnosprawnych, zgodnie z aktualnymi wytycznymi [10] [11] [12].

Pomimo iż parametry projektowanych przejść nie stwarzają wymagań do doświetlania w ciągu dnia przestrzeni tuneli w sposób inny niż tylko światłem wpadającym przez wloty po obydwu stronach [9], autorzy proponują dodatkowe doświetlenie za pomocą świetlików sufitowych, tam gdzie ich instalacja jest możliwa z uwagi na obecność pasa rozdzielającego jezdnie, lub świetlików opartych na zasadzie działania peryskopu. Taki świetlik byłby rurowym przewodem z umieszczonym wewnątrz układem luster, transferujących światło pobrane poza obrębem jezdni do doświetlających okien usytuowanych w ścianach tunelu (rys. 4). Lokalizacja tych okien w suficie tunelu nie jest brana pod uwagę ze względu na dążenie do zapewnienia stropowi tunelu jak najmniejszej wysokości konstrukcyjnej. 
a) SKALA $1: \frac{200}{1000}$
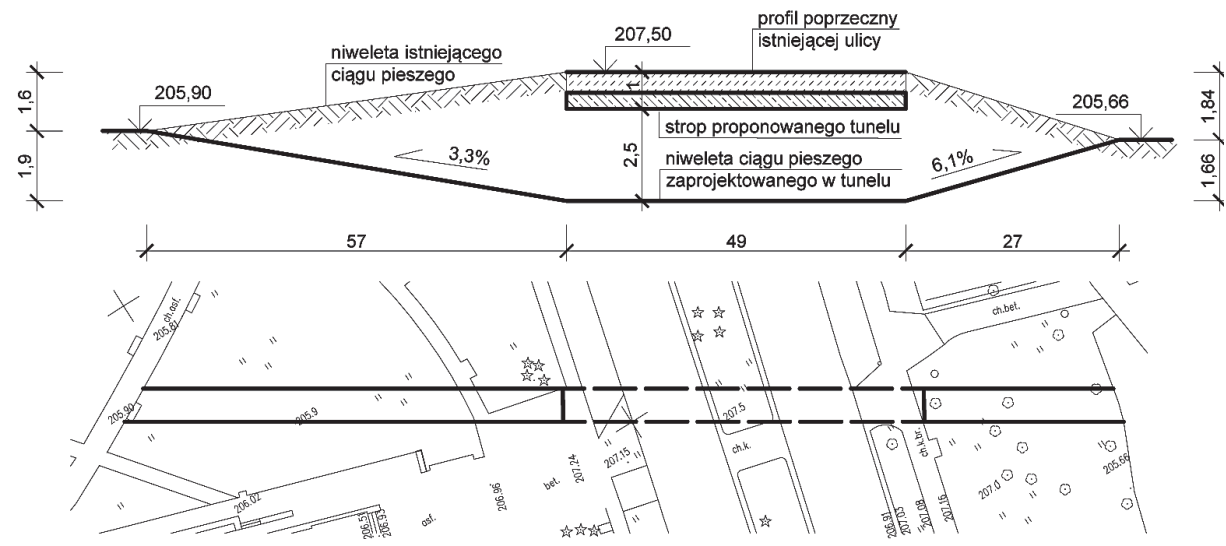

b)

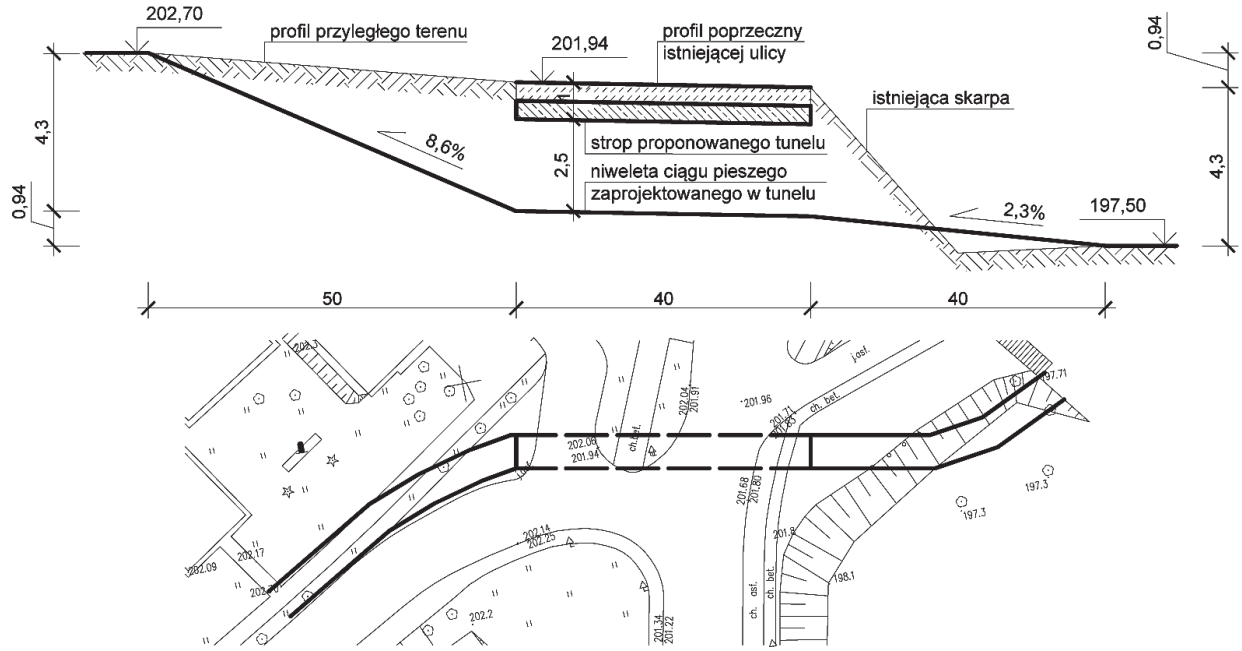

c)

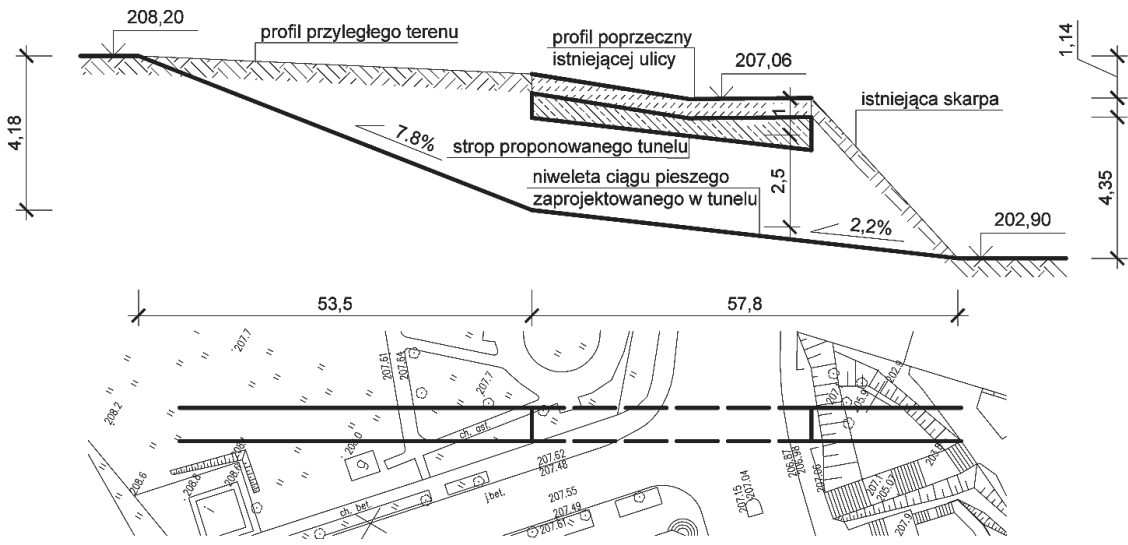

Rys. 3. Możliwe do zrealizowania profile przejść podziemnych pod ulicami: a) al. Cieplińskiego b) ul. Szopena, c) skrzyżowaniem ul. Dąbrowskiego i ul. Reformackiej (opracowano na podstawie mapy geodezyjnej z 2017 roku) 

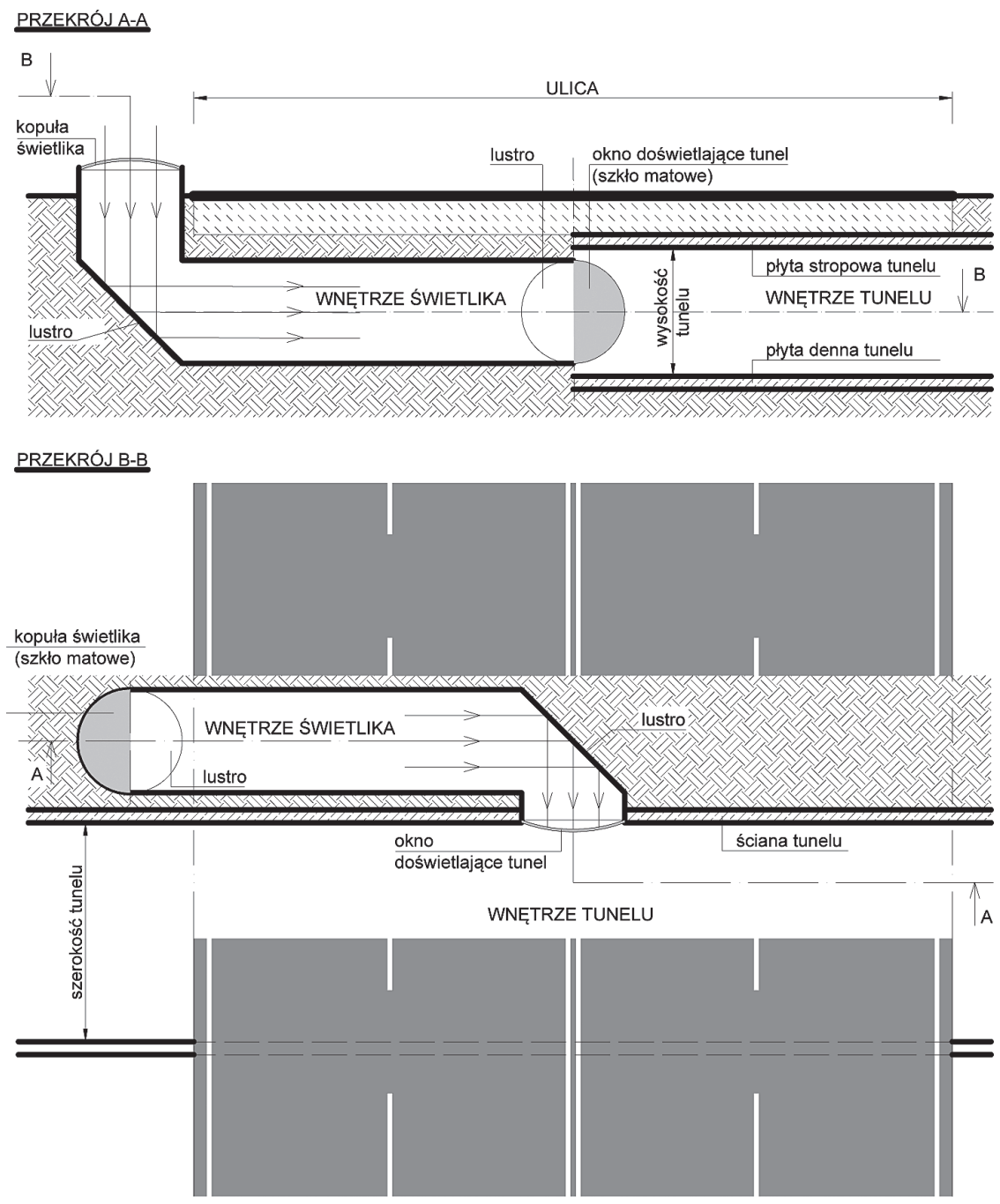

Rys. 4. Propozycja doświetlenia tunelu za pomocą świetlika opartego na zasadzie działania peryskopu

\section{Podsumowanie}

W artykule przedstawiono zarys koncepcji rozbudowy ogólnomiejskiej przestrzeni publicznej w Rzeszowie tak, aby stanowiła ona jednolitą sieć szlaków pieszo-rowerowych, przenikającą się ze szlakami dla ruchu pojazdów samochodowych w bezpieczny sposób. W newralgicznych punktach przecięć tych szlaków zapewnione są skrzyżowania bezkolizyjne, zaś w innych miejscach bezpieczeństwo pieszych jest chronione za pomocą sygnalizacji świetlnej lub środków uspokojenia ruchu samochodowego. Struktura sieci pomyślana jest z intencją jak najszerszego zaprezentowania jej użytkownikom dziedzictwa historycznego zawartego w krajobrazie architektoniczno-kulturowym miasta.

Realizacja wszystkich zamierzeń, przedstawionych w fazie wstępnej procesu architektonicznego [13] [14] [15], wymaga ogromnych nakładów finansowych oraz kosztów 
społecznych i może być postrzegana tylko, jako rozłożona w długim okresie czasowym. Nie istnieją jednak żadne przeszkody, aby była wykonywana etapami. Wśród elementów projektu są i takie, które mogą być zrealizowane stosunkowo łatwo i bez większych nakładów inwestycyjnych. Zagadnieniem pominiętym w opracowaniu jest kwestia zrównoważenia znaczącego ubytku miejsc postojowych dla samochodów, wynikającego z wyłączenia ruchu samochodowego na niektórych ulicach, lub zwężenia jezdni, w związku z potrzebą wytyczenia szerokiego ciągu pieszo-rowerowego. Utrata miejsc postojowych może być zrekompensowana tylko poprzez budowę parkingów wielopoziomowych, dla których istnieją w centrum miasta dogodne lokalizacje.

Projekt przedstawiony w artykule może stać się kanwą dla opracowań szczegółowych, dotyczących poszczególnych wnętrz urbanistycznych, również takich, które znajdują się w bezpośrednim sąsiedztwie analizowanej przestrzeni, zaś same nie zostały w niniejszym tekście wymienione. Autorzy są przekonani, że realizacja choćby części spośród przedstawionych propozycji, rozwiniętych w procesie projektowym do rozwiązań atrakcyjnych pod względem funkcjonalnym i estetycznym, przyczyniłaby się do istotnego podniesienia jakości zamieszkiwania w Rzeszowie, promując miasto jako miejsce do osiedlania się oraz służyła poprawieniu jego profilu wizerunkowego [16].

\section{Literatura}

[1] Nowa Karta Ateńska 2003 - wizja miast XXI wieku. Towarzystwo Urbanistów Polskich 2003.

[2] Problematyka ochrony dziedzictwa kulturowego i zabytków w studiach uwarunkowań $i$ kierunków zagospodarowania przestrzennego gmin oraz $w$ miejscowych planach zagospodarowania przestrzennego. Poradnik dla planistów i samorządów lokalnych (red. J. Welc-Jędrzejewska), Narodowy Instytut Dziedzictwa, Warszawa 2011.

[3] Gehl J. Życie między budynkami. Użytkowanie przestrzeni publicznych. Wydawnictwo RAM, Kraków 2013.

[4] Lorens P. Definiowanie wspótczesnej przestrzeni publicznej. [w:] Problemy kształtowania przestrzeni publicznych (red. P. Lorens, J. Martyniuk-Pęczek), Wydawnictwo Urbanista, Gdańsk 2010, str. 6-20.

[5] Ferenc T. Rzeszowska droga rozwoju - od drewnianych ulic do stolicy innowacji. Wykład z okazji przyznania tytułu doktora honoris causa Politechniki Rzeszowskiej wygłoszony w dniu 19 maja 2017 roku.

[6] Piekarski M., Prokopska A., Gotkowska E., Prokop A. Koncepcja integracji Ogrodu Miejskiego w Rzeszowie z przestrzenia publiczna Starego Miasta. Czasopismo Inżynierii Lądowej, Środowiska i Architektury 64(3/II) (2017) 257-272.

[7] Gehl J. Miasta dla ludzi. Wydawnictwo RAM, Kraków 2014.

[8] Ochrona pieszych. Podręcznik dla organizatorów ruchu pieszego. (red. K. Jamroz), Ministerstwo Infrastruktury i Rozwoju, Gdańsk, Kraków, Warszawa 2014.

[9] Rozporządzenie Ministra Transportu i Gospodarki Morskiej w sprawie warunków technicznych, jakim powinny podlegać obiekty inżynierskie i ich usytuowanie. Dz.U.2000.63.735.

[10] Poradnik-organizacja przestrzeni ulic w obszarach śródmiejskich. Ministerstwo Infrastruktury i Rozwoju, Warszawa 2013.

[11] Dostępna przestrzeń publiczna. Fundacja Instytut Rozwoju Regionalnego, Kraków 2009.

[12] Projektowanie i adaptacja przestrzeni publicznej do potrzeb osób niewidomych i słabowidzących - zalecenia i przepisy. Polski Związek Niewidomych, Warszawa 2016.

[13] Prokopska A. Zastosowanie metody analizy morfologicznej w projektowaniu architektonicznym na przykładzie twórczości Le Corbusiera. Oficyna Wydawnicza Politechniki Rzeszowskiej, Rzeszów 1997. 
[14] Prokopska A. Projektowanie architektoniczne. Procesy wstępne. Oficyna Wydawnicza Politechniki Rzeszowskiej, Rzeszów 2012.

[15] Prokopska A. Metodologia projektowania architektonicznego: fazy wstępne procesu architektonicznego. Oficyna Wydawnicza Politechniki Rzeszowskiej, Rzeszów 2015.

[16] Prokopska A., Martyka A. Miasto jako organizm przyjazny czlowiekowi. Budownictwo i Architektura 16(1) (2017) 165-174.

\title{
Recreational corridors for pedestrian and cyclists as the means of formation of identity of Rzeszów residents
}

\author{
Maciej Piekarski, Aleksandra Prokopska \\ Department of Architectural Design and Engineering Graphics, \\ Faculty of Civil and Environmental Engineering and Architecture, Rzeszow University of Technology, \\ e-mail: mgpiekar@prz.edu.pl,aprok@prz.edu.pl
}

\begin{abstract}
The subject of the paper deals with issues of selection of fragments of urban structure important for the Rzeszów history and tradition and integration of less exposed areas with the area of intensively exploited public space, in order to strengthen the identity of the inhabitants of the city. Characteristic changes in the spatial structure of Rzeszów are the proliferation of public space and its weakening in the historic area of the city, caused by the cutting of streets with significant traffic volume. The lack of public functions within the center is also conditioned by the accessibility for cars of most of the streets in this area. The only enclave of pedestrian and bicycle traffic is the Market Square, Kosciuszko and May 3 streets and parts of Mickiewicz and Grunwaldzka streets. The second zone is the recreation area on the river Wisłok. Both areas are popular among the Rzeszow community, but according to the authors, their capacity does not meet the needs. The paper presents the idea of combining both areas and incorporating into the homogeneous zone of pedestrian and bicycle traffic other, currently separated, areas specific by historical pedigree, including parks. An essential element of the concept are the non-collision crossings of designed roads with the car arterias, with the aid of underground passages, which thanks to the terrain configuration would be accessible by ramps, and their spaces, sunlit and visually visible externally, would not constitute a psychological barrier. Other proposed actions are the elimination or restriction of movement of cars, or the possibility of parking on some streets, correction of tree stand in order to exposition of architectural dominants, etc.
\end{abstract}

Keywords: Rzeszów, public space, urban identity, cultural landscape. 
